\title{
PROTECTING PRIVACY
}

\author{
Hector MacQ ueen \\ (2004) 8 E dinburgh L aw Review pp 249-254
}

O ne anticipated effect of the coming into force of the Human Rights Act was judicial reconsideration in the light of Article $8 \mathrm{ECHR}$ (right to privacy) of the previous denial by the English courts of such a right. ${ }^{1}$ And indeed there has been a considerable amount of litigation on the subject since 20 ctober 2000; litigation which incidentally has assumed rather than argued out the issue of horizontality of Convention rights under the Human Rights Act, but has not definitively clarified the nature of the horizontality. There has also been no declaration that English law now recognises a general right of privacy. Instead, what has happened has been the gradual extension of the law of breach of confidence into areas where previously it would have had no place. ${ }^{3}$ The main extensions can be summarised thus: (1) the widening scope of the information recognised as confidential, the assessment of which includes the impact of the form of the proposed publication, the test being whether the disclosure would be highly offensive to a reasonable person of ordinary sensibilities and would shock the conscience (rather than the more privacy-oriented approach of asking whether the information fell within the private sphere); and (2) there may be an obligation of confidentiality even although the information was not really imparted in a relation of confidence. It is the latter which pushes the developing tort of breach of confidence closest to a privacy action. ${ }^{4}$

However, as Lindsay J pointed out in D ouglas v $\mathrm{H}$ ello!, ${ }^{5}$ one of the leading examples of this extension of breach of confidence, "further development by the courts may merely be awaiting the first post-Human Rights Act case where neither the law of confidence nor any other domestic law protects an individual who deserves protection" ${ }^{6}$

\footnotetext{
${ }^{1}$ M alone v M etropolitan Police C ommissioner [1979] Ch 344; Kaye v Robertson [1991] FSR 62.

2 On the 'horizontality' of the Human Rights Act 1998, see H L MacQueen and D Brodie, "Private rights, private law and the private domain", in A Boyle, C Himsworth, A Loux and H MacQ ueen (eds), H uman Rights in Scots L aw (2002); and, for further references, H L MacQ ueen, "Human rights and private law in Scotland: a response to President Barak", [2003] 78 T ulane L aw Review forthcoming.

${ }^{3}$ The main cases are: D ouglas v H ello! [2001] Q B 967 (CA); V enables and Thompson v N ews G roup N ewspapers L td [2001] 2 WLR 1038 (Q B, Butler-Sloss P);T heak ston v Mirror G roup N ewspapers L td [2002] EWHC 137 (QB); A v B and C [2003] Q B 195; C ampbell v M irror G roup N ewspapers [2002] EWHC 499 (Q B); rev'd [2003] Q B 633(CA); D ouglas v H ello! [2003] 3 All ER 996 (Lindsay J); X, a woman formerly k nown as M ary Bell v 0’Brien [2003] EWHC QB 1101; [2003] EMLR 37 (Q B, Butler-Sloss P).

${ }^{4}$ See for full discussion G Phillipson, "Transforming breach of confidence? Towards a common law of privacy under the Human Rights Act", (2003) 66 M L R 726-758, and J Morgan, "Privacy, confidence and horizontal effect: 'Hello' trouble", (2003) 62 C LJ 444-473.

5 [2003] 3 All ER 996 (Lindsay J).

6 D ouglas v H ello!, para 229.
} 
Lindsay J drew attention to the latest European Court of Human Rights case on the subject, Pedk v U nited Kingdom , decided on 28 January 2003, ${ }^{7}$ in which P's Article 8 rights were held to have been infringed by a local authority's publication of closed circuit TV camera pictures of him carrying a knife in a public street. The context in which this had occurred, however, was P's attempt to commit suicide by slashing his wrists with the knife while suffering from clinical depression. The authority's publication of the material had been intended to show how the use of CCTV could deal with dangerous situations the police had been prompted to arrest $\mathrm{P}$ after sighting the images - but the publicity failed to disguise P's identity. Lindsay J added:

[Pedk] shows that in circumstances where the law of confidence did not operate our domestic law has already been held to be inadequate. That inadequacy will have to be made good and if Parliament does not step in then the courts will be obliged to. ${ }^{8}$

Nevertheless, the House of Lords has now ruled that, at any rate before 2 O ctober 2000, English law did not have a general tort of invasion of privacy although the case in question was not covered even by the extended action for breach of confidence. The alleged invasion in $\mathrm{W}$ ainwright v $\mathrm{H}$ ome 0 ffice ${ }^{9}$ was strip-searches of visitors to a prison by prison officers, which went beyond what was allowed under (non-statutory) prison rules, and caused emotional distress to one victim and post-traumatic stress disorder to the other, a young man with physical and learning difficulties. The purpose of the searches was the detection of drugs being smuggled into the prison for prisoners, a major problem in British prisons. Although the case is thus concerned with a very specific situation, the speech of Lord Hoffmann is clearly intended to be of wider scope. Thus, although the facts of $\mathrm{W}$ ainwright occurred before 2 October 2000, Lord Hoffmann expresses the obiter view that Article 8 was not infringed by the strip-search unless the harm done by the invasion of privacy was inflicted intentionally. He also suggests that Peck v U nited Kingdom showed, not that English law failed to protect privacy, but that a system of control of CCTV cameras was needed to protect the sensitivities of persons whose image was captured by the all-seeing lens. This, he went on, required the detailed approach of legislation rather than the broad brush of common law principle. A number of the other cases in which it had been held that English law did not protect privacy had been dealt with subsequently by way of legislation: telephone tapping by the Interception

7 (2003) 36 EHRR 41.

8 D ouglas v H ello!, para 229.

9 [2003] UKHL 53; [2003] 3 WLR 1137 (HL). 
of Communications Act 1985, ${ }^{10}$ "stalking" through the Protection from Harassment Act 1997, police surveillance by the Police Act 1997. In addition there was the D ata Protection Act 1998, regulating the processing of personal data and providing a civil action against misuse. Privacy was too protean a concept to lend itself to other than this kind of detailed protection, together with an appropriate range of exceptions, which could be achieved only by statutory provision.

It is not altogether clear where this decision leaves the law with regard to events after $2 \mathrm{O}$ ctober 2000. The Human Rights Act means that there is a statutory remedy against invasions of individual privacy by a public authority (i.e. in vertical cases), but Lord Hoffmann is careful to avoid "pre-emption" of "the controversial question of the extent, if any, to which the Convention requires the state to provide remedies for invasions of privacy by persons who are not public authorities", ${ }^{11}$ (i.e. in horizontal cases). The House of Lords may have the opportunity to consider that question when they hear $\mathrm{C}$ ampbell v M irror $\mathrm{G}$ roup $\mathrm{N}$ ewspapers, ${ }^{12}$ a case between a private individual and a newspaper (the Press not being a public body). Here the privacy issues are the publication of personal information and surreptitiously taken photographs; for the newspaper there is also an issue about Press freedom of expression, since it published the information to counter untrue publicity about herself put about by Campbell. The case so far has proceeded on the basis of breach of confidence and the D ata Protection Act. ${ }^{13}$ The House may be faced with the question of whether the law in this area has moved so far to take account of Article 8 ECHR that it should be re-labelled invasion of privacy, with breach of confidence being returned to its narrower former ambit; and if so, whether this newly developed tort should be confined to media intrusions upon private life, or left potentially wide enough to reach the wholly different problems illustrated by the W ainwright case. Lord Hoffmann's speech will make it very difficult to take the latter step; and he also expresses some doubts about the former. ${ }^{14}$

W ainwright is therefore, despite the fact that it deals with facts before 20 ctober 2000, a demonstration of the difficulties some, and perhaps most, English judges will feel in using Article $8 \mathrm{ECHR}$ to develop the common law to create a general obligation to respect individual privacy. In part, these difficulties stem from the view that, like good

\footnotetext{
${ }^{10}$ Now replaced by the Regulation of Investigatory Powers Act 2000 and the Regulation of Investigatory Powers (Scotland) Act 2000.

${ }^{11}$ At para. 34.

${ }^{12}$ For references for the decisions of the courts below, see above, n. 2. The case was heard by the House of Lords on 18 and 19 February 2004.

${ }^{13}$ There are also claims under the D ata Protection Act, under which the case may ultimately be decided.

${ }^{14}$ See paras. 28-31 of Lord Hoffmann's speech.
} 
faith in contract, or strict liability in delict, privacy is so multi-faceted that generalisation by judges arising from particular cases is dangerous, and that the responsibility for the creation of a general right, if that is needed or desirable, should fall on the legislature. Where the legislature wishes to act to protect privacy, it has done so. In the case of media intrusion, the $\mathrm{G}$ overnment has clearly wished not to intervene directly, but rather to encourage and support Press and broadcaster self-regulation through voluntary codes, while the Human Rights Act itself seeks to privilege freedom of expression amongst human rights by requiring courts to have "particular regard" for its importance. ${ }^{15}$ It is not for the judges to undo that approach by developing sweeping common law regulation where none or little existed before.

O ne may also detect in W ainwright the traditional English suspicion of general principles and the preference for regulating specific problems piecemeal. Lord Bingham's rejection of good faith on those grounds is well-known; ${ }^{16}$ and even after a general principle is identified, as in the case of negligence, the courts often develop it only incrementally and within established categories of cases. ${ }^{17}$ Privacy, as with other interests, is protected, but in pockets of liability, rather than in general. There is too a hint of English law being founded on freedoms rather than rights, when Lord Hoffmann rejects the relevance of the breach by the prison officers of the non-statutory prison rules on strip searches: "the acts of the prison officers needed statutory authority only if they would otherwise have been wrongful, that is to say, tortious or in breach of statutory duty." 18

The apparent conclusion that strip searching is not a wrong unless made so by positive law is however surprising if the prison saw fit to regulate the practice by its own internal rules; and one might also ask questions about the Wainwrights' freedom not to be intimately touched by others. As Lord Hoffmann rightly says, "having to take off your clothes in front of a couple of prison officers is not to everyone's taste", ${ }^{19}$ even less so is then having your private parts fingered and handled by the officers in question. The surprise is all the greater to observers from a legal system which takes a more

\footnotetext{
${ }^{15}$ Human Rights Act, s. 12; and see further the G overnment's negative response (Cm 5985, October 2003) to the Fifth Report of the House of Commons Culture, Media and Sport Select Committee on Privacy and Media Intrusion (HC 458-1, June 2003) and its recommendation of the introduction of a new privacy law against media intrusion.

16 "English law has, characteristically, committed itself to no such over-riding principle [of good faith] but has developed piecemeal solutions in response to demonstrated problems of unfairness" (Interfoto Picture L ibrary L td v Stiletto V isual Programmes L td [1989] QB 433, per Bingham LJ, at 439).

${ }_{17}$ See C aparo v D idk man Industries [1990] 2 AC 605 at 618 per Lord Bridge of Harwich.

${ }^{18}$ At para. 7.

${ }^{19}$ At para. 3.
} 
generalised approach to delictual liability than that apparent in W ainwright. In the preHuman Rights Act Scottish case of $\mathrm{H}$ enderson v C hief C onstable of Fife, ${ }^{20}$ Mrs Henderson was in police custody, subject to a lawful detention; but the police, following a normal practice for which there was no statutory authority, required her to remove her bra while she remained in a police cell. This was to prevent her using the garment to harm herself, even although there was no indication of any danger of this being at all likely in the particular situation. Lord Jauncey held that the police action was a clear invasion of Mrs Henderson's liberty without justification, from which it followed that she had a remedy in damages. He continued:

I should perhaps add that the researches of counsel had disclosed no Scottish case in which it had been held that removal of clothing forcibly or by requirement could constitute a wrong but since such removal must amount to an infringement of liberty I see no reason why the law should not protect the individual from this infringement. ... I consider that an award of $£ 300$ would fairly reflect the invasion of privacy and liberty which Mrs Henderson suffered as a result of having to remove her brassiere. ${ }^{21}$

Apart from this case and its clear contrast in approach with that of Lord Hoffmann in W ainwright, however, modern Scots law has been non-committal on the subject of privacy, although in an unreported case in 1957 Lord Justice Clerk Thomson said: "I know of no authority to the effect that mere invasion of privacy however hurtful and whatever its purpose and however repugnant to good taste is itself actionable."22

The law of South Africa clearly takes a much more generalised approach to delictual liability which by way of the actio injuriarum achieved the protection of privacy, founded upon the concept of individual dignitas, long before the enactment of the Bill of Rights. ${ }^{23}$ It seems clear that a person's naked body is regarded as part of their "inner sanctum", not to be intruded upon by others intentionally or with animus injuriandi (consciousness of wrongfulness). That animus is presumed if the invasion of privacy is proved; strict liability is imposed if the wrong affects the liberty of the subject. There are defences such as statutory authority and, perhaps, following the Bogoshi case,

\footnotetext{
201988 SLT 361.

21 At 367.

22 M urray v Beaverbrook N ewspapers Second Division, 18 June 1957. See further M A Hogg, "The very private life of the right to privacy", (1994) 2(3) H ume Papers on Public Policy 1-28.

${ }^{23}$ See generally for what follows D McQ uoid-Mason, "Invasion of privacy: Common law v constitutional delict - does it make a difference?", [2000] A cta Juridica 227.
} 
reasonableness. This is now reinforced ${ }^{24}$ by the constitutional protection of dignity and privacy, which includes a prohibition upon searching the person, although this may be subject to justification under the limitations clause. ${ }^{25}$

The truism that no right is to be considered absolute, implies that from the outset of interpretation each right is always already limited by every other right accruing to another citizen. In the context of privacy this would mean that it is only the inner sanctum of a person, such as his/ her family life, sexual preference and home environment, which is shielded from erosion by conflicting rights of the community. This implies that community rights and the rights of fellow members place a corresponding obligation on a citizen, thereby shaping the abstract notion of individualism towards identifying a concrete member of civil society. Privacy is acknowledged in the truly personal realm, but as a person moves into communal relations and activities such as business and social interaction, the scope of personal space shrinks accordingly. ${ }^{26}$

The Constitution does however mean that searching of a person must have a legal basis, which in turn must respect the limits created by the Constitution. ${ }^{27}$ It has been suggested that to be constitutionally valid laws giving power to search must define the power and provide for appropriate prior authorisation. ${ }^{28}$ Fault is not a requirement for an invasion of the constitutional right to privacy.

Long ago T B Smith suggested that the principles of the actio injuriarum might also be a basis in Scots law for challenging "the infliction of affront upon an individual by invading his privacy" ${ }^{29}$ When he was a Scottish Law Commissioner, the Commission put forward a comparison with South African law in this respect. ${ }^{30}$ But there have been few signs of any subsequent development of this comparative nature by the Scottish courts. In April 2003, however, arguments based upon the actio injuriarum were deployed in a case concerned with the admissibility of evidence procured by private investigators through intrusions upon an individual's privacy contrary to Article 8 ECHR, by way of unasked-for visits to his home and surveillance of his house from a neighbouring

\footnotetext{
${ }^{24} \mathrm{O}$ the relationship between the common law and the Constitution in the context of privacy protection see Bernstein v Bester N 01996 (2) SA 751 (CC).

${ }^{25}$ Constitution of the Republic of South Africa 1996, sections 1, 14, 36.

26 Bernstein v Bester N 0 (above, n. 23), per Ackermann J, at para. 67.

${ }^{27}$ Mistry v Interim N ational Medical and D ental Council 1998 (4) SA 1127 (CC).

${ }^{28} \mathrm{~J}$ de Waal, I Currie and G Erasmus, The Bill of Rights H andbook (4th edn, 2001), 277.

29 T B Smith, A Short C ommentary on the L aw of Scotland (1962), at 655-656.

30 Scottish Law Commission Memorandum No 40, Confidential Information (April 1977), 28-35.
} 
property. ${ }^{31}$ Counsel for the pursuer argued that the court had a duty to develop the existing law to be compatible with the ECHR, and that the adtio injuriarum provided a basis for protection of privacy in Scots law. Counsel for the defenders, referring to Reinhard Zimmermann's book on the law of obligations ${ }^{32}$ and the Digest, argued that the principles of the adtio injuriarum were not wide enough to cover privacy in general, but only attacks on personality for an unlawful purpose. The purpose of the surveillance here, to discover whether or not the party being watched was truly suffering from the injury for which he was claiming damages in a delict action, was not unlawful. Lord Bonomy merely recorded the submissions made on this point, however, and decided the case on other grounds, giving little support to any development of the law in this particular way.

In conclusion, the judicial power to develop the common law in the light of human rights protection depends, not only on the factors which have traditionally, and quite properly, hemmed in the judges, such as respect for the legislature and recognition of the limits of their own vision of policy, but also on the legal culture in which the judges themselves have operated. The contrast between the general English and the South African legal cultures is clear in the area of privacy. Nor is privacy the only example of this English reluctance to take on board the generalising tendencies of Convention rights: as Conor G earty has remarked of the approach in criminal law, "at times it has seemed as though the operating assumption has been that the Human Rights Act 1998 must be interpreted 'as far as possible' to be compatible with pre-existing law, rather than the other way round". ${ }^{33}$ So far as concerns the impact of human rights law, much of the difference between South Africa and England has to do with the very different social, political and economic realities in which the two systems took human rights on board; ${ }^{34}$ but it is a fair question whether the English approach has always reached the right conclusions, even against a different overall background. In particular, while the $\mathrm{W}$ ainwright case may or may not be rightly decided as a matter of the law applying in England before 2 October 2000, it is submitted that it cannot govern the result on facts arising after that date. The right approach then will be to ask whether the

\footnotetext{
${ }^{31}$ Martin v M oG uiness 2003 SCLR 548.

32 R Zimmermann, The L aw of O bligations; Roman F oundations of the Civilian Tradition (1990, repr 1996).

33 "The Human Rights Act and the criminal law: an overview of the early case-law", in A Boyle, C

Himsworth, A Loux and H MacQ ueen (eds), H uman Rights in Scots L aw (2002), at 294. The reference is to

Human Rights Act 1998, s 3(1).

34 I explore some of these differences in background and their legal-cultural effects in "D elict, contract and the Bill of Rights: a perspective from the United Kingdom”, (2004) 121 South A frican L aw Journal

forthcoming.
} 
private sphere of persons such as the Wainwrights has been invaded (answer, surely, yes) and, taking into account Article 8's self-limitation to allow for "the prevention of disorder or crime, protection of health or morals [and protection of the rights and freedoms of others" as well as the Human Rights Act's privileging of freedom of expression against other Convention rights, ${ }^{35}$ whether that invasion was justified in the whole circumstances of the case.

And what of the Scots? The legal culture of Scotland, at least when it comes to judicial development of the law and the approach to general principles, is probably closer to that of England than that of modern South Africa, despite the neo-Civilian crusade of T B Smith and others to make it otherwise. ${ }^{36}$ But, as shown by the contrast between the case of $\mathrm{H}$ enderson and the decision in W ainwright, acculturation has by no means reached the point of complete assimilation. Indeed, it is worth noting that Lord Jauncey, who decided the $\mathrm{H}$ enderson case, was a conservative even amongst Scottish judges. ${ }^{37}$ Those same Scottish judges were, at least to begin with, much more adventurous with the ECHR than their English counterparts, although their enthusiasm may have been tempered by the outcomes of subsequent appeals to and decisions of the House of Lords and the Judicial Committee of the Privy Council. ${ }^{38}$ At least with regard to privacy, however, the way is still open, it is suggested, for the Scottish courts to take their own approach to the question, and to develop a general principle informed by Article 8 of the ECHR, and subject therefore to the other Articles of the Convention and such general defences as may seem appropriate in that light and under other principles of the common law. In that process, lessons can certainly be learned from the jurisprudence being developed under the Southern Cross.

Hector L MacQ ueen

E dinburgh L aw School

\footnotetext{
${ }^{35}$ Human Rights Act, s 12.

36 On T B Smith's interest in human (or, as he preferred to call them, basic or fundamental) rights, see my forthcoming paper, "Two Toms and an ideology for Scots law: T B Smith and Lord Cooper of Culross", to appear in a volume of essays about Smith and his work.

${ }^{37}$ See e.g. his dissent in W oolwich E quitable Building Society v Inland Revenue C ommissioners [1993] 1 AC 70; his very reluctant assent in Smith v Bank of Sootland 1997 SC (HL) 111; and his refusal to accept the argument of principle in Sharp v Thomson 1997 SC (HL) 66.

38 See e.g. Starrs v Rux ton 2000 JC 208; H oek stra v H M A dvocate (N os 1-4) 2000 JC 387, 391, 599; 2001 SC (PC) 37; 2001 JC 131; Brown v Stott 2001 SC (PC) 43; M Intosh v H M A dvocate 2001 SC (PC) 89; Millar v Dick son 2002 SC (PC) 30; County Properties L td v Soottish Ministers 2000 SLT 965, rev'd 2002 SC 79, after the decision of the House of Lords in R v Secretary of State for E TR, ex parte A lconbury [2003] 2 AC 295. See also H M A dvocate v R 2003 SC (PC) 21, where three Scottish Law Lords formed a majority over two English ones on an ECHR point (but none the less an appeal from the High Court of Justiciary, for which see 2001 SLT 1366 and 2002 SLT 834, was allowed). This case has now been reviewed by nine judges (including two Scots) in the House of Lords from an English perspective, and by a majority of 7-2 (the 2 being the Scots judges), a different result has been reached: A ttorney-G eneral's R eference N 02 of 2001 [2004] 2 WLR 1. The constitutional implications of this are unclear.
} 